\title{
SLC22A2 Gene
}

National Cancer Institute

\section{Source}

National Cancer Institute. SLC22A2 Gene. NCI Thesaurus. Code C107574.

This gene is involved in mediating the uptake of organic compounds. 